\title{
Antibacterial Effect of Granati fructus Cortex Extract on Streptococcus mutans In Vitro
}

\author{
Cut R. Alfath ${ }^{1}$, Vera Yulina ${ }^{1}$, Sunnati ${ }^{2}$ \\ ${ }^{1}$ Undergraduate Program, Dentistry Study Program, Faculty of Medicine, University of Syiah Kuala, Banda \\ Aceh 23111, Indonesia \\ ${ }^{2}$ Dentistry Study Program, Faculty of Medicine, University of Syiah Kuala, Banda Aceh 23111, Indonesia \\ Correspondence e-mail to: vera.canina28@gmail.com
}

\begin{abstract}
The rind of pomegranate fruit (Granati fructus cortex) composed of antibacterial compounds such as alkaloid, flavonoid and tannin. Objective: To evaluate the bacterial effect of Granati fructus cortex extract against Streptococcus mutans. Methods: The study was laboratory experimental. The inhibition test was performed by agar diffusion method on MHA medium. Results: It showed the bacterial property of Granati fructus cortex on various concentration. The highest extract concentration of 30\% extract has the largest of inhibition zones $(15.4 \mathrm{~mm})$. The results showed a difference in the size of inhibition zones related to different extract concentrations. Conclusion: This study confirmed the antibacterial effect of Granati fructus cortex on the growth of Streptococcus mutans.
\end{abstract}

\begin{abstract}
ABSTRAK
Efek antibakteri ekstrak kulit buah delima (Granati fructus cortex) pada Streptococcus mutans in vitro. Granati fructus cortex mengandung senyawa-senyawa antibakteri seperti alkaloid, flavonoid, dan tannin. Tujuan: Mengevaluasi efek antibakteri Granati fructus cortex dalam menghambat pertumbuhan Streptococcus mutans. Metode: Penelitian ini merupakan eksperimental laboratoris yang menguji daya hambat antibakteri menggunakan metode difusi agar dengan media MHA. Hasil: Ekstrak kulit buah delima dalam berbagai konsentrasi memiliki efek antibakteri, ekstrak kulit buah delima dengan konsentrasi 30\% memiliki rata-rata zona hambat paling besar $(15,4 \mathrm{~mm})$. Semakin tinggi konsentrasi ekstrak kulit buah delima maka semakin besar zona hambat yang terbentuk. Hasil uji ini juga menunjukkan adanya perbedaan rata-rata zona hambat dalam berbagai konsentrasi ekstrak kulit buah delima. Simpulan: Granati fructus cortex memiliki efek antibakteri terhadap pertumbuhan Streptococcus mutans.
\end{abstract}

Key words: antibacterial effect, Granati fructus cortex, Streptococcus mutans

\section{PENDAHULUAN}

Streptococcus mutans (S.mutans) adalah bakteri Gram positif yang dapat memetabolisme karbohidrat terutama sukrosa dan menciptakan suasana asam di rongga mulut. ${ }^{1}$ S.mutans mempunyai dua sistem enzim pada dinding sel yang dapat membentuk dua polisakarida ekstraseluler dari sukrosa. ${ }^{2}$ Sukrosa dihidrolisis menjadi fruktosa (levan) dan glukosa (dekstran). Fruktosa dihidrolisis oleh enzim fruktosiltransferase dan glukosa dihidrolisis oleh enzim glukosiltransferase. ${ }^{1,2}$ Fermentasi sukrosa akan menghasilkan penurunan $\mathrm{pH}$ saliva menjadi 5,0 atau lebih rendah. Ketika $\mathrm{pH}$ plak turun di bawah 5,0, dapar saliva terganggu dan menyebabkan pelepasan ion kalsium dan fosfat dari kristal hidroksiapatit. ${ }^{3}$
Demineralisasi email dapat terjadi karena peningkatan konsentrasi asam laktat sehingga dapar saliva tidak cukup untuk mencegah larutnya email, selanjutnya proses karies dapat terjadi. ${ }^{1,3} S$. mutans merupakan bakteri penyebab awal terjadinya karies karena adanya variasi faktor-faktor virulensi yang khas pada bakteri yang telah diisolasi. ${ }^{3}$ S. mutans merupakan bakteri anaerob yang dikenal memproduksi asam laktat sebagai bagian dari metabolismenya dan mampu melekat pada permukaan gigi dengan adanya sukrosa sebagai substrat. ${ }^{3,4}$

Dalam dekade terakhir ini banyak penelitian yang ditujukan untuk pengembangan tumbuhan sebagai sumber bahan obat. Untuk memenuhi keperluan perawatan kesehatan dasar, diperkirakan sekitar 75\%- 
$80 \%$ penduduk desa di dunia menggunakan bahan obat yang berasal dari tumbuhan, dan sekitar $28 \%$ dari tumbuhan di bumi telah dipakai sebagai bahan obat tradisional. ${ }^{5}$ Rumusan obat-obat nasional menyebutkan kurang lebih 23 negara menggunakan delima sebagai obat resmi. ${ }^{6}$ Di Indonesia ada dua macam delima yang sering ditanam, yaitu delima merah dan putih. Delima putih sangat kaya akan kandungan alkaloid dan flavonoid. Kulit buah, kulit akar dan kulit batang delima mempunyai khasiat sebagai obat sakit gigi. Air rebusan buah dan kulit buah delima dapat dipakai sebagai obat kumur secara tradisional .

Kulit buah delima mempunyai kandungan kalium yang tinggi, selain mineral-mineral seperti fosfor, kalsium, besi, natrium, dan vitamin-vitamin seperti vitamin A, B1, B2, B3, dan C. Kalium bersama natrium, mengatur keseimbangan air di dalam tubuh dan menjaga detak jantung agar tetap normal. Kulit buah delima putih memiliki sifat antibakteri terhadap beberapa bakteri di rongga mulut. ${ }^{5}$ Kulit buah delima mengandung senyawa alkoloid pelletierene, granatin, betulic acid, ursolic acid, isoquercitrin, elligatanin, resin, triterpenoid, kalsium oksalat, dan pati. Kulit buah delima mengandung alkaloid dan flavanoid yang mempunyai aktivitas antimikroba terhadap S. mutans. ${ }^{7}$

Penelitian ini bertujuan untuk mengetahui pengaruh ekstrak buah delima terhadap pertumbuhan bakteri $S$. mutans, dan mengetahui gambaran daya hambat ekstrak buah delima terhadap bakteri $S$. mutans dalam berbagai konsentrasi $(15 \%, 20 \%, 25 \%$, dan 30\%). Hipotesis penelitian ini adalah ekstrak Granatifructus cortex mempunyai daya hambat terhadap S.mutans dan akan terdapat perbedaan efek antibakteri beberapa konsentrasi dari ekstrak Granati fructus cortex terhadap S. mutans.

\section{METODE}

Penelitian ini merupakan penelitian eksperimental laboratorium. Penelitian dilakukan di Laboratorium Penelitian Fakultas Matematika dan Ilmu Pengetahuan Alam (FMIPA) dan di Laboratorium Mikrobiologi Fakultas Kedokteran Hewan Universitas Syiah Kuala, Banda Aceh.

Bahan-bahan yang digunakan adalah: buah delima $2 \mathrm{~kg}$, etanol 95\% 2 liter, klorheksidin glukonat 2\% (Kimia Farma, Indonesia), dimethyl sulfoxide (DMSO), media TYS20B, $\mathrm{NaCl}$ 0,85\%, alkohol 70\%, dan biakan S. mutans. Alat-alat yang digunakan adalah: rotary evaporator, disk kosong (Oxoid), inkubator (Fishers scientific), oven (Gallenkamp, Jerman), kaliper geser (Tricebrand, China), pipet volume (Pyrex, Japan), ose dan kapas lidi, autoklaf (Nacro e series model 9000$D$, Germany), cawan petri, lampu spiritus, gelas ukur
(Pyrex, Japan), botol vial, pinset (Smic, Japan), hot plate (Fisons, UK), Pipet mikro, pipetman starter kit (Gilson, USA), rak tabung reaksi, spatula, aluminium foil, gelas ukur 500ml (Pyrex, Japan), neraca analitik (Ohaus), dan tabung reaksi (Pyrex, Japan).

Bahan-bahan pembuat media terlebih dahulu ditimbang dengan menggunakan timbangan analitik. Media TYS yang 20B digunakan: sukrosa 200g, Yeast Extract $10 \mathrm{~g}$, Trypticase Soy Agar 40g, Bacto Agar 5g, dan Bacitrasin 4mg/0,004g (200 UI). Setelah bahan-bahan tersebut ditimbang, dimasukkan ke dalam tabung erlenmeyer dan ditambahkan $1000 \mathrm{ml}$ aquades steril. Selanjutnya dilakukan homogenisasi dan dipanaskan di atas hot plate hingga mendidih. Kemudian disterilkan dalam autoklaf pada suhu $121^{\circ} \mathrm{C}$ selama 15 menit. Setelah bahan agak dingin, dimasukkan ke dalam cawan petri secara asepsis menggunakan lampu spiritus.

\section{Pembuatan ekstrak etanol buah delima}

Buah delima sebanyak $2 \mathrm{~kg}$ dibersihkan, diambil kulitnya kemudian dikeringkan selama 24 jam pada suhu kamar, dilanjutkan dengan proses maserasi dengan merendam dalam etanol menggunakan botol tertutup berwarna gelap selama 24 jam.

Hasil maserasi disaring kemudian dipekatkan menggunakan alat rotary evaporator pada suhu tidak lebih dari $50^{\circ} \mathrm{C}$, sehingga pelarut etanol terpisah dengan ekstrak tumbuhan. Ekstrak kental yang diperoleh kemudian dimasukkan ke dalam botol steril. Konsentrasi ekstrak kulit buah delima sebanyak 15\%, $20 \%$, 25\%, dan 30\%, masing-masing didapat dengan melarutkan ekstrak kulit buah delima dalam larutan DMSO yang merupakan bahan alami dari serat kayu dan tidak berbahaya. Larutan DMSO berfungsi sebagai pelarut yang cepat meresap ke dalam epitel ekstrak tanpa merusak sel-sel tersebut dan sering digunakan dalam bidang kedokteran dan kesehatan. Ekstrak yang telah dilarutkan, kemudian dimasukkan ke dalam botol yang telah steril dan disimpan pada suhu $4^{\circ} \mathrm{C}$ sampai waktu digunakan.

\section{Pembiakan bakteri $S$. mutans}

Bakteri yang digunakan adalah bakteri $S$. mutans dari biakan murni yang terdapat di Laboratorium Biologi FMIPA UNSYIAH. Biakan bakteri dilakukan dalam suasana aerob pada cawan petri berisi media TYS20B dan diinkubasi dalam suasana aerob pada suhu $37^{\circ} \mathrm{C}$ selama 24 jam, lalu pertumbuhan $S$. mutans diamati. Apabila pertumbuhan bakteri tidak subur dan terjadi kontaminasi bakteri lain, maka prosedur pembiakan bakteri dan pengamatan diulang kembali. Sebanyak 1-2 ose dari biakan murni bakteri uji, dilarutkan dengan $\mathrm{NaCl}$ 0,85\% sampai diperoleh kekeruhan yang sama

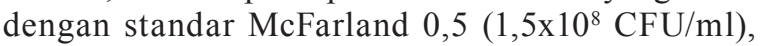
kemudian disebarkan pada media MHA. 


\section{Uji efektifitas antibakteri metode difusi agar}

Cakram kosong diambil dan diletakkan pada piring petri steril dengan menggunakan pinset steril. Empat cakram kosong digunakan untuk masing-masing bahan coba kemudian diteteskan $15 \mu$ l bahan coba menggunakan pipet mikro dan didiamkan selama 60 menit. Suspensi bakteri dengan konsentrasi $1,5 \times 10^{8}$ colony forming units (CFU)/ml diusapkan secara merata mengunakan kapas lidi pada media Mueller Hinton Agar (MHA) dalam piring petri. Setelah diusapkan, dibiarkan selama 30 menit supaya bakteri meresap ke dalam agar. Setelah persiapan dilakukan, cakram yang ditetesi bahan coba diletakkan pada media MHA mengikut area yang telah dibuat untuk masing-masing bahan coba. Setelah itu, media dimasukkan ke dalam inkubator pada suhu $37^{\circ} \mathrm{C}$ dan diamati setelah 18 dan 24 jam. Zona hambat yang terbentuk diukur dengan kaliper geser. Klasifikasi respon hambat pertumbuhan bakteri dilakukan berdasarkan metode yang telah dikembangkan sebelumnya (Tabel 1).

\section{HASIL}

Hasil uji daya hambat ekstrak Granati fructus cortex terhadap pertumbuhan $S$. mutans pada media MHA menunjukkan terbentuknya zona hambat yang berupa zona terang disekitar kertas cakram dapat dilihat pada Gambar 1. Hasil pengamatan pada konsentrasi ekstrak kulit buah delima antara konsentrasi $15 \%$ dan $25 \%$ menunjukkan adanya peningkatan rata-rata diameter zona hambat dari 10,2mm ke 13,6mm. Konsentrasi ekstrak kulit buah delima antara konsentrasi 20\% dan $30 \%$ juga menunjukkan peningkatan rata-rata diameter zona hambat dari $12,8 \mathrm{~mm}$ harus diubah ke $15,4 \mathrm{~mm}$. Kontrol positif tidak memiliki zona hambat rata-rata paling besar, tetapi ekstrak kulit buah delima dengan konsentrasi 30\% memiliki zona hambat ratarata yang paling besar.

Hasil analisis parametik one-way ANOVA memperlihatkan adanya perbedaan rata-rata diameter zona hambat yang bermakna $(p<0,05)$ antara berbagai konsentrasi ekstrak kulit buah delima dalam menghambat pertumbuhan $S$. mutans. Uji Games Howe digunakan untuk melihat perbedaan yang bermakna dari variasi konsentrasi ekstrak kulit buah delima dalam menghambat pertumbuhan $S$. mutans. Uji ini menunjukan konsentrasi $15 \%$ memiliki perbedaan bermakna dengan konsentrasi 25\%,30\%, dan kontrol positif. Konsentrasi $20 \%$ tidak memiliki perbedaan bermakna dengan konsentrasi 15\%, 25\%, 30\%, dan kontrol positif. Hasil uji lanjut di atas juga menunjukkan bahwa konsentrasi 30\% memang memiliki zoha hambat rata-rata yang paling tinggi $(15,4 \mathrm{~mm})$, akan tetapi tidak memiliki perbedaan yang bermakna dengan kontrol positif yaitu 15,2mm.
Tabel 1. Klasifikasi respon hambat pertumbuhan bakteri ${ }^{8}$

\begin{tabular}{cc}
\hline $\begin{array}{c}\text { Diameter } \\
\text { Zona Terang }\end{array}$ & $\begin{array}{c}\text { Respon } \\
\text { Hambatan Pertumbuhan }\end{array}$ \\
\hline$>20 \mathrm{~mm}$ & Kuat \\
$16-20 \mathrm{~mm}$ & Sedang \\
$10-15 \mathrm{~mm}$ & Lemah \\
$<10$ & Tidak ada \\
\hline
\end{tabular}

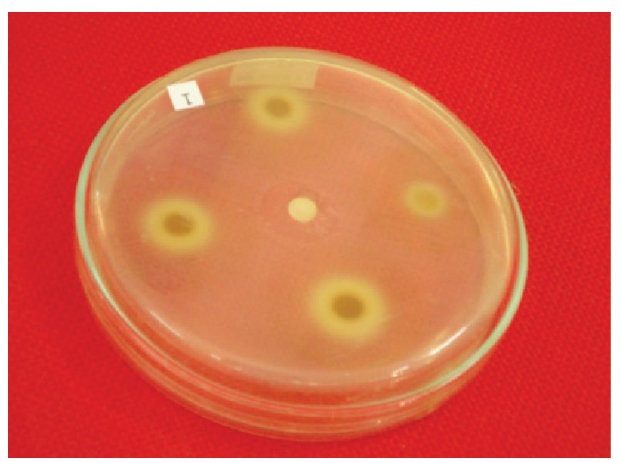

Gambar 1. Zona hambat $S$. mutans pada kelompok kontrol dan kelompok perlakuan

\section{DISKUSI}

Penelitian ini fokus pada efek anti-bakteri berbagai konsentrasi ekstrak kulit buah delima terhadap S. mutans, agen kausatif utama penyebab karies pada manusia. Kemampuan bakteri ini melekat pada permukaan gigi merupakan hal terpenting bagi perkembangan karies. ${ }^{1}$ Metode yang digunakan pada penelitian ini adalah metode tes difusi agar. Pengukuran zona hambat dilakukan setelah 18 sampai 24 jam menggunakan jangka geser. Zona hambat merupakan daerah tempat terdapatnya zona bening di sekeliling kertas cakram yang menunjukkan adanya daya hambat ekstrak kulit buah delima dan klorheksidin glukonat $0,2 \%$ sebagai kontrol positif terhadap $S$. mutans. ${ }^{8}$

S. mutans memiliki berbagai faktor virulensi seperti adesi, kolonisasi, dan bersifat asidofilik. Tidak seperti spesies bakteri lain yang terdapat pada plak, metabolisme bakteri menurun pada suasana $\mathrm{pH}$ yang rendah, namun metabolisme $S$. mutans meningkat pada $\mathrm{pH}$ rendah. Hal ini disebabkan karena sistem daya proton yang digunakan untuk transpor nutrisi dapat menembus dinding selnya pada $\mathrm{pH}$ rendah serta kadar glukosa tinggi, dan kandungan ion hidrogen yang meningkat pada keadaan asam. S. mutans mampu menurunkan pH rongga mulut dan mempertahankan nilai keasaman yang tidak alami. Kondisi ini menguntungkan metabolisme $S$. mutans dan tidak menguntungkan bagi spesies lain yang hidup pada waktu bersamaan. ${ }^{1}$

Pada penelitian ini, ekstrak kulit buah delima dibuat secara sederhana dengan menggunakan rotary evaporator. Ekstraksi maserasi merupakan suatu metode yang sering digunakan untuk mendapatkan senyawa dari tumbuhan 
dengan menarik senyawa organik dalam suatu bahan padat menggunakan pelarut organik.9 Pelarut yang digunakan adalah etanol 95\%. Proses maserasi pada kulit buah delima akan mengeluarkan senyawa-senyawa aktif yang akan diikat oleh pelarut yang digunakan. Penelitian yang telah dilakukan membuktikan bahwa kulit buah delima merupakan suatu tanaman alami yang mengandung zat-zat (misalnya alkaloid, flavonoid, dan tanin) yang dipercaya dapat menghambat pertumbuhan S. mutans dan sebagai tanaman antibakteri. ${ }^{10}$

Penelitian yang dilakukan sebelumnya mengungkapkan bahwa ekstrak metanol yang terdapat pada kulit buah delima mampu melawan bakteri Staphylococcus aureus, Escherichia coli, Pseudomonas aeruginosa, Salmonella typhi, dan Candida albicans. ${ }^{11}$ Penelitian tersebut belum menyebutkan bahwa bakteri $S$. mutans dapat dihambat pertumbuhannya oleh kulit buah delima. ${ }^{11}$ Penelitian sebelumnya juga menunjukkan bahwa ekstrak kulit buah delima me-nempati urutan kelima dalam menghambat S. mutans dibandingkan dengan berbagai ekstrak herbal lainnya. ${ }^{12}$

Konsentrasi ekstrak kulit buah delima 15\%, 20\%, $25 \%$, dan $30 \%$ kemudian dibandingkan dengan klorheksidin glukonat $0,2 \%$ sebagai kontrol positif. Klorheksidin glukonat merupakan antiseptik bersifat kimia yang banyak digunakan sebagai bahan obat kumur karena sifatnya yang dapat membunuh bakteri Gram positif serta Gram negatif. Klorheksidin bersifat netral dengan $\mathrm{pH}$ 5-7 di dalam rongga mulut. Interaksi ini akan mengikat permeabilitas dinding sel bakteri yang menyebabkan terjadinya penetrasi ke dalam sitoplasma. Ion kalium merupakan substansi pertama yang dapat dilihat ketika membran sitoplasma dihancurkan. Perubahan permeabilitas dari membran sitoplasma dapat menyebabkan presipitasi sari protein sitoplasma, perubahan keseimbangan osmosis, gangguan metabolisme, pemisahan sel, hambatan membran ATP, pencegahan proses anaerob, dan kematian mikroorganisme.

Hasil analisis statitik dengan one-way ANOVA memperlihatkan adanya perbedaan rata-rata diameter zona hambat yang bermakna $(p<0,05)$ antara berbagai konsentrasi ekstrak kulit buah delima dalam menghambat pertumbuhan S. mutans. Hasil penelitian uji daya hambat yang dilakukan pada media padat MHA menunjukkan bahwa semakin tinggi konsentrasi ekstrak kulit buah delima maka semakin besar zona hambat yang terbentuk di sekitar kertas cakram. Beberapa faktor yang mempengaruhi adanya zona hambat bergantung kepada kemampuan difusi bahan antimikroba ke dalam media dan interaksinya dengan mikroorganisme yang diuji, jumlah mikroorganisme yang digunakan, kecepatan tumbuh mikroorganisme yang diuji, dan sensitivitas mikroorganisme terhadap bahan antimikroba yang diuji. Bahan pelarut yang digunakan juga memiliki pengaruh terhadap terbentuknya zona hambat di sekitar cakram herbal. Selain itu zat ekstraktif yang terkandung pada tumbuhan itu sendiri juga memiliki pengaruh pada daya hambat kulit buah delima terhadap pertumbuhan S. mutans. ${ }^{13}$

\section{SIMPULAN}

Dari hasil penelitian ini, dapat disimpulkan bahwa sediaan ekstrak kulit buah delima mampu secara efektif menghambat pertumbuhan S. mutans. Semakin tinggi konsentrasi ekstrak kulit buah delima, maka semakin besar zona hambat yang terbentuk terhadap pertumbuhan S. mutans. Bahan ini berpotensi sebagai obat alternatif antibakteri rongga mulut.

\section{DAFTAR PUSTAKA}

1. Simon L. The role of Streptococcus mutans and oral ecology in formation of dental caries. LURJ [Internet]. 2007 [cited $20128 \mathrm{Mar}$; Available from:https:// www.uleth.ca/dspace/handle/10133/1196.

2. Rowson JE, Slaney AE. Dentistry. 1st ed. Delhi, India: AITB, 2001.

3. Roeslan BO. Metabolisme karbohidrat oleh Streptococcus mutans: pembentukan plak dan terjadinya karies gigi. Jurnal PDGI. 1992;4: 8-12. Indonesian.

4. Nakano K, Nomura R, Nakagawa I, Hamada S, Ooshima T. Demonstration of Streptococcus mutans with a cell wall polysaccharide specific to a new serotype $\mathrm{k}$ in the human oral cavity. J Clin Microbiol. 2004;42:198-202.

5. Farnswoth NR, Soejarto DD. Global importance of medical plants. Cambridge Univ Press; 1991.

6. Heyne K. Tumbuhan berguna Indonesia II. Badan Penelitian dan Pengembangan Kehutanan Departemen Kesehatan RI, Jakarta, 1987. Indonesian.

7. Samarayanake L. Essential microbiology for dentistry. 3rd ed. Elsevier: Churchill Livingstone; 2006.

8. Greenwood D. Antimicrobial and chemotherapy. Michigan: Oxford University Pres: 2000.

9. Nurcahyati H. Evaluasi pH ekstrak daun teh ( $\mathrm{Ca}$ mellia sinensis) terhadap pertumbuhan Streptococcus mutans. Banda Aceh [skripsi] Program Studi Kedokteran Gigi FK Unsyiah, 2010. Indonesian.

10. Jurenka J. Therapeutic Applications of pomegranate (Punica granatum L): A review. Alter Med Rev. 2008;13:128-44.

11. Sastracaha G, Yotnuengnit P, Booncong P, Sangtherapitikul P. Adjunctive periodontal treatment with Centela asiatica and Punica granatum extracts. A preliminary study. J Int Acad Perio. 2003;5:106-15.

12. Syarif S. Skrining tumbuhan obat yang mempunyai aktifitas antibakteri penyebab karies gigi dan pembentuk plak. J Bahan Alam Ina. 2007;6:65-72. Indonesian.

13. Supriadi A. Sifat antibakteri zat ekstraktif kayu siwak (Salvadora persicawall) terhadap pertumbuhan Streptococcus mutans. [skripsi] Bogor: Fakultas Kehutanan IPB, 2009. Indonesian. 